\title{
種々の土質を用いた透水試験による ジオテキスタイルフィルターの目詰まり特性
}

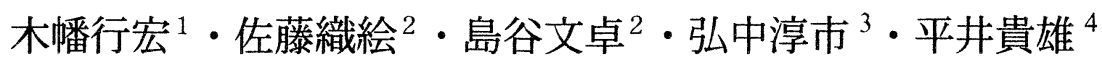

\begin{abstract}
ジオテキスタイルフィルターを敷設箇所の土質を考慮せずに暗渠等の濾過・分離材として使用した場合、土 粒子の浸入により目詰まりが発生し、垂直方向通水性能が低下し、所定の機能を満たさないことが考えられる.

本研究では、ジオテキスタイルフィルターの垂直方向通水性能に及ぼす土質種類の影響を検討するために、 愛鷹ローム・関東ローム・六戸細粒分質砂土層と磉層の間にジオテキスタイルを挟めた一連の定水位透水試験 を行った. その結果、ジオテキスタイルフィルターの垂直方向通水性能は各ジオテキスタイルにおける単位体 積目詰まり量と開孔径以下の粒径の通過質量百分率の関係に依存すること、また、目詰まり量及び単位体積目 詰まり量はジオテキスタイルの繊維構造の影響を受けることなどが示された.
\end{abstract}

キーワード : ジオテキスタイル, 目詰まり, 垂直方向通水性能, 透水係数, 透水試験, フィルター

\section{1. はじめに}

ジオテキスタイルを盛土の水平排水材として使用し た場合、主に問題とされるのが(1)土粒子の浸入・捕捉 に伴うジオテキスタイルの目詰まり、(2)盛土荷重によ って作用する拘束圧等の要因による通水性能の低下で ある ${ }^{1) ~ 4)}$ 。一方、排水層への土砂の浸入を防止する ため、グラウンド、ゴルフ場等の暗渠排水溝の周囲に 垂直方向の『濾過・分離材』としてジオテキスタイル を敷設した場合、面内方向と垂直方向の通水性能は相 互に関連することが知られており ${ }^{5)}$ 、垂直方向におい てもジオテキスタイルに目詰まりが発生し、通水性能 や分離機能が低下することが考えられる.一般に、『滤 過・分離材』として使用した場合のジオテキスタイル はジオテキスタイルフィルターと呼ばれており、ジオ テキスタイルフィルターの垂直方向通水性能に関する 目詰まり現象には、ジオテキスタイルの繊維構造内に 土粒子が浸入して発生する場合と、ジオテキスタイル 直上部に土粒子の細粒分が貯留されて発生する場合の 2 つの要因が挙げられている ${ }^{6)}$. 図-2 (a)、(b)に目詰 まり要因を模式的に示す.図-2 (a)が、前者の場合で、 図中の矢印で示されるように、ジオテキスタイル表面 の開孔径より小さい粒径の土粒子がジオテキスタイル 内部に浸入する状沉を示している. 図-2 (b) は、後者 の場合で、ジオテキスタイル表面の開孔径より大きい 粒径の土粒子が多いために、土粒子がジオテキスタイ

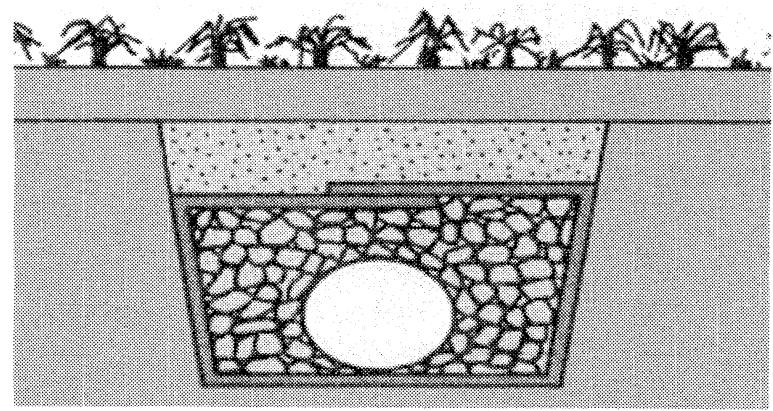

図一１ ジオテキスタイルの利用【濾過・分離材】

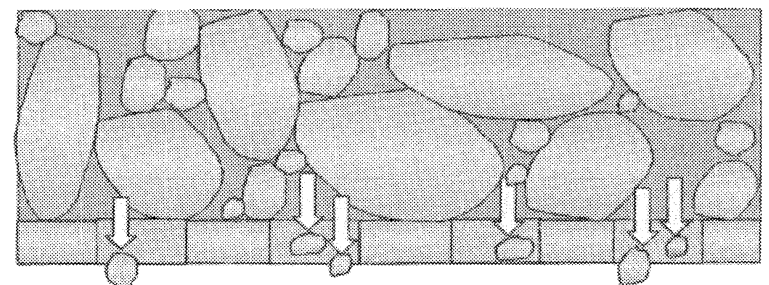

（a）土粒子がジオテキスタイル内に浸入する場合

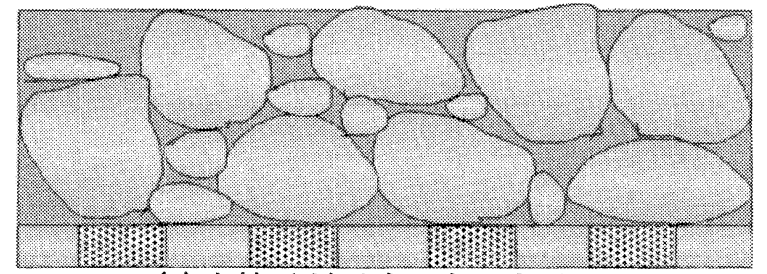

(b) 土粒子がジオテキスタイルの

直上部に貯留する場合

図一２＼cjkstart目詰まり要因の概念図

\footnotetext{
1正会員，室蘭工業大学，工学部，建設システム工学科，助教授（广050-8585北海道室蘭市水元町27-1）

2学生会員, 室蘭工業大学大学院, 工学研究科, 建設システム工学専攻（テ050-8585北海道室蘭市水元町27-1）

${ }^{3}$ 正会員，三井化学産資株式会社，技術開発部（テ346-028埼玉県久喜市河原井町9番地）

${ }^{4}$ 正会員，三井化学産資株式会社，事業本部（T113-0034東京都文京区湯島3丁目39-10）
} 
ルに浸入出来ず、ジオテキスタイルの直上部に粒子が 引っかかって留まる、すなわち貯留している状況を示 している.

本研究では、2つの要因のうち前者に着目して、3 種類の細粒な土とジオテキスタイルに対する定水位透 水試験結果から算出される透水係数の変化、目詰まり 量、単位体積目詰まり量 ${ }^{7)}$ 、ジオテキスタイルの開孔 径に着目して通水性能を検討した。

\section{2. 試料およびジオテキスタイルフィルター}

\section{1 試料}

本研究に使用した試料は、原位置から採取した、関 東ローム、愛鷹ローム、六戸細粒分質砂、室蘭細粒分 質砂（ほとんどシルト、以下、採取土と呼ぶ）、および 市販の甲州産安山岩砕石であり、これらの物理的性質 を表- 1 に、各々の粒径加積曲線を図-3に示す。ここ で、図中に示す $0_{95}$ は、ジオテキスタイル供試体を通過 したガラスビーズの粒径加積曲線より通過率 $95 \%$ に 対応するガラスビーズ径であり、一般に、見かけの開 孔径と呼ばれているものである。

なお、室蘭細粒分質砂は室蘭工業大学構内で採取し た土をふるい分けして、2 mmふるい通過分のみを使 用したものである.

\section{2 ジオテキスタイルフィルター}

本実験で使用したジオテキスタイル（不織布）は、 ポリプロピレン樹脂を原料とし、スパンボンド法によ り製造された連続長繊維不織布であり、4 種類のジオ テキスタイルを用いた. 表- 2 に比較・検討するジオテ キスタイルの物性值を示す，表- 2 中、GTX-S は 1 層構 造、GTX-D は 2 層構造のジオテキスタイルを表す。ま た、ジオテキスタイルの種類における数字は、目付け に基づいたものである.

\section{3. 試験装置および試験方法}

本研究で用いた試験装置は、図-4に示した定水位透 水試験装置である. 定水位透水試験装置は上部モ一ル ド、下部モールドから成る，以下に供試体作製方法と 試験方法を示す。

\section{1 供試体作製方法}

試験装置の上部モールドに甲州産安山岩砕石(以下、 礫と呼ぶ）層を、下部モ一ルドに試料土層を作製し、 その間にジオテキスタイルを挟めた.

砂層の作製は、砂が密になるように乾燥密度 1.487 $\mathrm{g} / \mathrm{cm}^{3}$ を目標としてハンマーで上部モ一ルドに振動を 与えながら礫を充填させた。一方、試料土層の作製に は $2.5 \mathrm{~kg}$ のランマーを用い、1 層の締固め回数を 55 回として 3 層締固めを行った。試験に用いるジオテキ スタイルは、飽和させるためにあらかじめ水に浸して おいた。

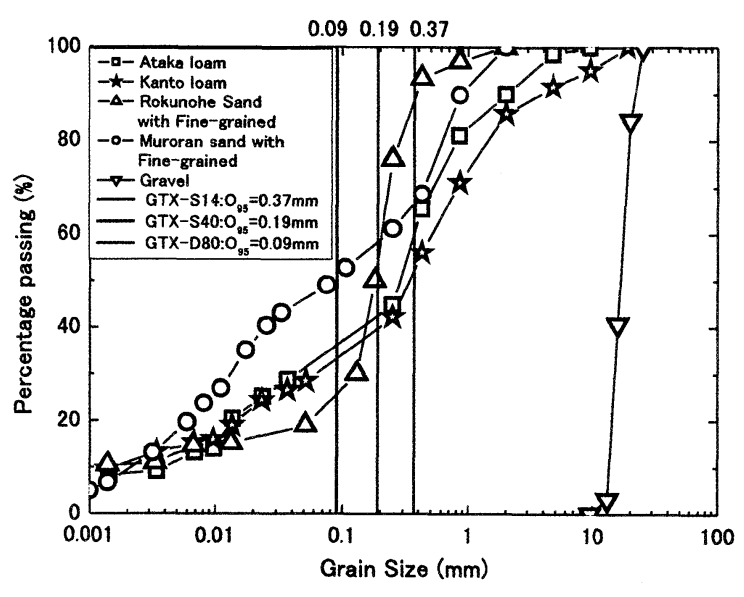

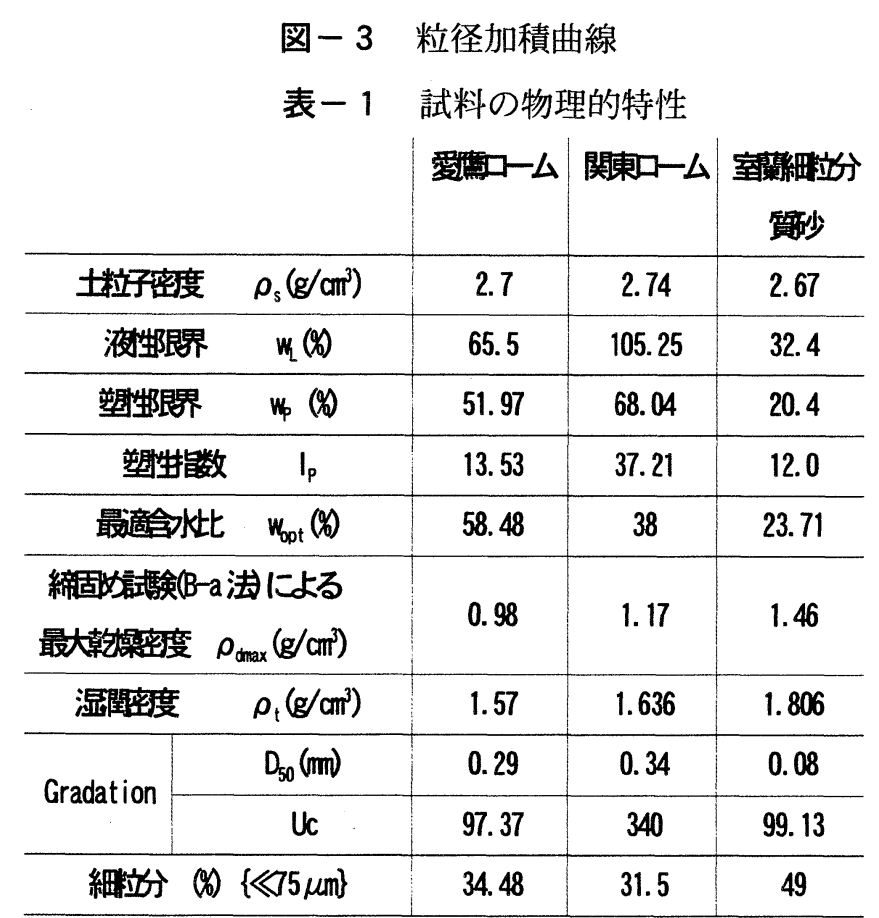

\begin{tabular}{|c|c|c|c|}
\hline & & 六細竕分算少 & 甲赃安山岩杂石 \\
\hline \multicolumn{2}{|c|}{ 土粒子密度 } & 2.74 & 2.75 \\
\hline 乾喿密度 & 最大密度 & 1. 369 & 1.54 \\
\hline$\rho_{\mathrm{d}}\left(\mathrm{g} / \mathrm{cm}^{3}\right)$ & 最必度 & 1.06 & 1.083 \\
\hline \multicolumn{2}{|c|}{ 最適含水比 } & 14 & - \\
\hline \multicolumn{2}{|c|}{$\begin{array}{c}\text { 締固好詿験(B-a法)による } \\
\text { 最大乾嬠密度 } \rho_{\text {dmax }}\left(\mathrm{g} / \mathrm{cm}^{3}\right)\end{array}$} & 1.63 & - \\
\hline \multicolumn{2}{|c|}{ 湿閏密度 $\quad \rho_{\mathrm{t}}\left(\mathrm{g} / \mathrm{cm}^{3}\right)$} & 1.745 & - \\
\hline \multirow{2}{*}{ Gradation } & $D_{50}(\mathrm{~mm})$ & 0.17 & 16.7 \\
\hline & $U_{c}$ & 143.88 & 1.32 \\
\hline \multicolumn{2}{|c|}{ 細拉分 (年) $\{\ll 75 \mu \mathrm{m}\}$} & 24.01 & 0 \\
\hline \multicolumn{2}{|c|}{$\begin{array}{c}\text { 本実験D供㫌体密度 } \\
\rho_{\mathrm{d}}\left(\mathrm{g} / \mathrm{cm}^{3}\right)\end{array}$} & 1.63 & 1.487 \\
\hline
\end{tabular}




\begin{tabular}{|c|c|c|c|c|c|}
\hline ジオテキス & $\begin{array}{c}\text { 表 }-2 \\
\text { タイルの種類 }\end{array}$ & $\begin{array}{l}\text { オテキス } \\
\text { GTX-S14 }\end{array}$ & $\begin{array}{l}\text { タイルの物 } \\
\text { GTX-S30 }\end{array}$ & $\begin{array}{l}\text { 性値 } \\
\text { GTX-S40 }\end{array}$ & GTX-D80 \\
\hline \multicolumn{2}{|c|}{ 目付け $\left(\mathrm{g} / \mathrm{m}^{2}\right)$} & 140 & 300 & 400 & 800 \\
\hline \multicolumn{2}{|l|}{ 厚さ (mm) } & 1.5 & 3.0 & 4 & 6.5 \\
\hline \multicolumn{2}{|c|}{ 見かけの開孔径 (mm) } & 0.37 & 0.22 & 0.19 & 0.09 \\
\hline \multirow{2}{*}{$\begin{array}{l}\text { 透 水 係 数 } \\
(\mathrm{cm} / \mathrm{sec})\end{array}$} & 垂直 & $1 \times 10^{-1}$ & $1 \times 10^{-1}$ & $1 \times 10^{-1}$ & $1 \times 10^{-1}$ \\
\hline & 水平 & $1 \times 10^{-0}$ & $1 \times 10^{-0}$ & $1 \times 10^{-0}$ & $1 \times 10^{-0}$ \\
\hline
\end{tabular}

\section{2 試験方法}

定水位透水試験は、脱気水を透水試験装置の下端か ら給水し供試体に水を通水させ、上端から排水する方 法で行った．その際、試験に要する時間を短縮するた めに、動水勾配は現場で想定される值（ $\mathrm{i}=0.1 \sim 1.0)$ より大きい $\mathrm{i}=4$ に設定し、試験開始後に所定の経過時 間ごとに流量を計測した．本研究では、土質種類とジ オテキスタイルの種類による目詰まり特性の比較・検 討を目的としていることから、その全体的傾向に動水 勾配の影響は少ないと考えて実験を行った．また、定 水位透水試験終了後、透水試験装置から取り出したジ オテキスタイルの両面を 3 回ずつ濯ぎ、乾燥させてか ら試験後のジオテキスタイルの質量を測定して、目詰 まり量を算出した.

\section{4. 透水性亡目詰まり量の関係}

ジオテキスタイルフィルターの透水性と目詰まり量 の関係を検討するため、強制的に目詰まりを発生させ たジオテキスタイル（以下、目詰まりジオテキスタイ ル）を使用して、定水位透水試験を行った.

\section{1 目詰まりジオテキスタイルの作製方法}

目詰まりジオテキスタイルは次の手順で作製した. 1）ジオテキスタイルを十分に水浸させてから定水位 透水試験装置に設置し、ペースト状の採取土をジオテ キスタイルの全面に塗り付け、透水試験を行う.また、 ジオテキスタイルの目詰まり量をパラメータとするた めに、塗り付けるペース卜状採取土の質量を大・中 ・ 小の 3 種類とした. 2) ペースト状の採取土の土粒子が ジオテキスタイル上に残留し、通水が困難な状態とな

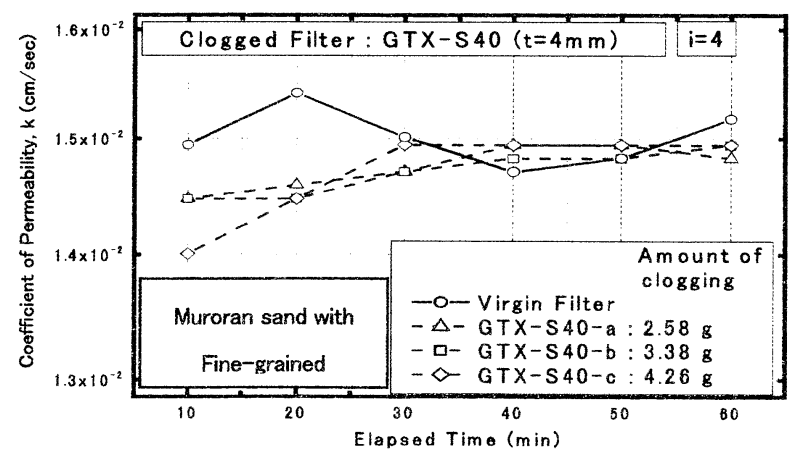

図一 5 透水係数一経過時間 （目詰まり GTX-S40）

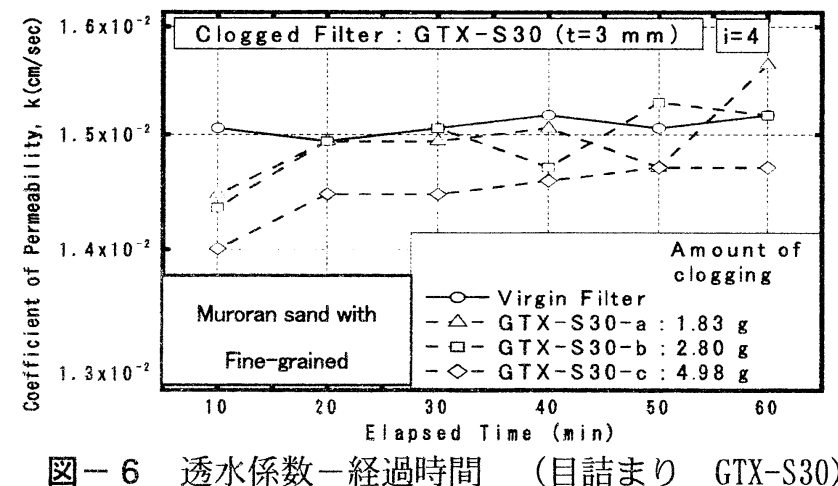

図-6 透水係数一経過時間 （目詰まり GTX-S30）

ればジオテキスタイルを取り出す.3）取り出したジオ テキスタイルの両面を 3 回ずつ濯ぎ、表面に付いた土 を取り除き、自然乾燥させる，その後、試験後のジオ テキスタイルの質量を計測し、試験前のジオテキスタ イルの質量から差し引くと目詰まり量として、GTX-S40 では、2.58g、3.38g、4.26g の目詰まりジオテキスタ イルが得られた. GTX-S30では、1.83g、2.80g、4.98g の目詰まりジオテキスタイルが得られた.

\section{2 目詰まりジオテキスタイルの定水位透水}

\section{試験}

定水位透水試験は、試験装置に目詰まりジオテキス タイルを設置し、上部及び下部モールドを脱気水で満 たした後、装置の下端から脱気水を流入させることに より行った. 試験終了後、ジオテキスタイルを取り出 し、自然乾燥させてジオテキスタイルの質量を計測す ることにより、目詰まり量を計測した。

図-5、6には、ジオテキスタイル GTX-S40、GTX-S30 の透水係数と経過時間の関係をそれぞれ示している.

図-5より、GTX-S40 については、目詰まりジオテキ スタイルの透水係数の值 (図中, $\triangle, \diamond, \square$ 印) が時間の 経過と共に増加傾向を示していることが分かる．経過 時間 10 分での透水係数の值に注目すると、目詰まりジ オテキスタイルの透水係数の值は目詰まりさせていな いジオテキスタイルの值よりも小さく、経過時間 30 分くらいから一定值に近づく．これは、透水試験終了 後の目詰まり量が、透水試験前よりも減少していたこ 


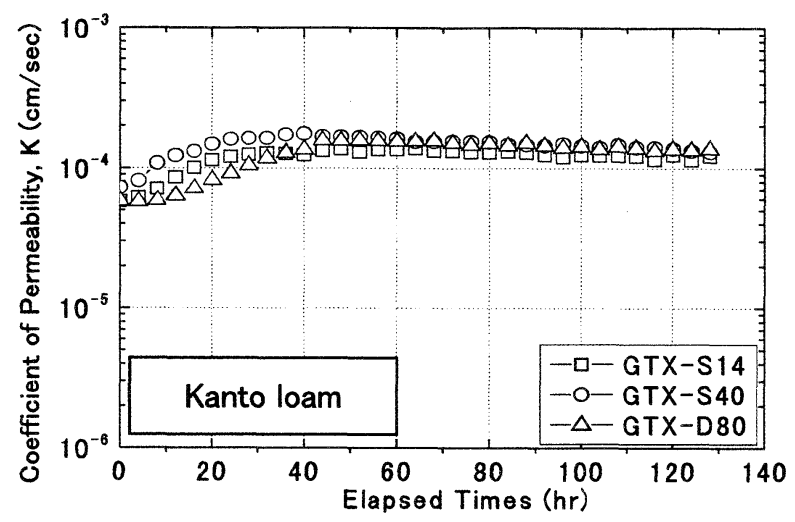

図-7 透水係数一経過時間の関係 (関東ローム)

とから、定水位透水試験中にジオテキスタイルから 土粒子が流出しているものと考えられる.

図-6に示す GTX-S30 については、GTX-S40 と同様 に目詰まりジオテキスタイルの透水係数の值が時間 の経過と共に増加傾向を示している．また、経過時 間 10 分においても GTX-S40 と同様に、目詰まりジオ テキスタイルの透水係数の值は目詰まりさせてない ジオテキスタイルの值よりも小さい. したがって、 GTX-S30 の場合においても GTX-S40 と同様に、定水 位透水試験中にジオテキスタイルから土粒子が流出 しているものと考えられる。また、GTX-S30-c は GTX-S30-a ¿ GTX-S30-b よりも、全体的に透水係数 が低くなった。 これは、GTX-S30-c が GTX-S30-a と GTX-S30-b よりも目詰まり量が多く、ジオテキスタ イル内に留まる土粒子が多くなったためであると考 えられる.

以上より、ジオテキスタイルの目詰まり量が大き いほど、透水係数が小さくなることが確認された.

\section{5. 透水係数と目詰まり評価の検討}

\section{1 種々の土に対する透水係数の検討}

種々の土に対して実施した定水位透水試験による

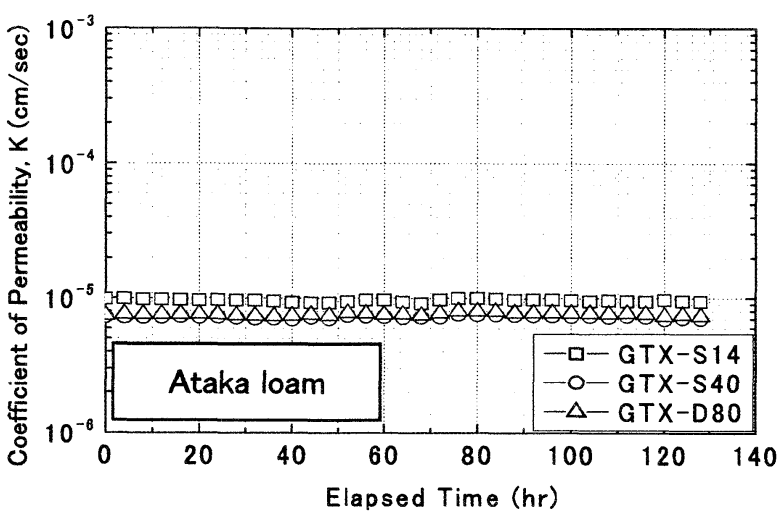

図-8 透水係数一経過時間の関係 (愛鷹口ーム)

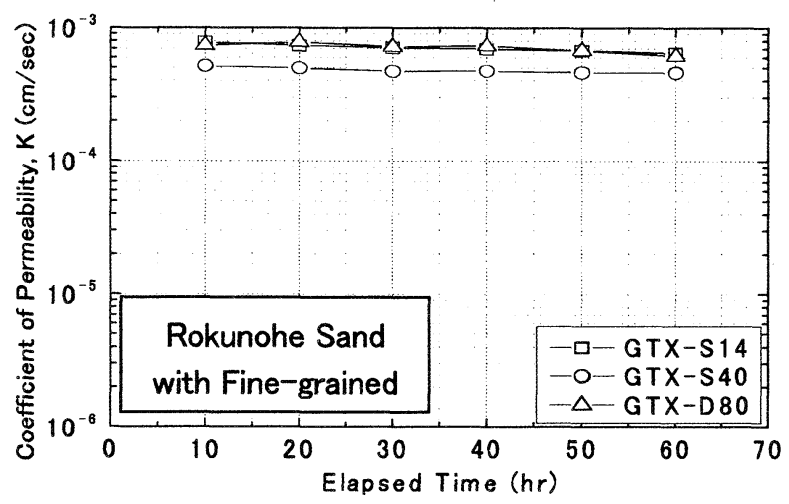

図-9 透水係数一経過時間の関係 （六戸細粒分質砂）

装置全体にわたる透水係数と経過時間の関係を図-7 〜 9に示す.それぞれ、図-7 は関東ローム、図-8 は 愛鷹口ーム、図-9 は六戸細粒分質砂の結果である. なお、対象としたジオテキスタイルは GTX-S14、 GTX-S40、GTX-D80 である. GTX-S30 は GTX-S40 に類 似したジオテキスタイルであるため試験には用いて いない.

透水係数の低下の要因として、ジオテキスタイル の目詰まり量だけでなく、試料土層の透水性の低下 も報告されていることから ${ }^{6)}$ 、本研究では目詰まり 現象が試料土層、ジオテキスタイル、礫層にわたる 全体の透水係数 $\mathrm{k}$ の減少傾向として現れると考えた.

表ー3 目詰まり量及び単位体積目詰まり量

\begin{tabular}{|c|c|c|c|c|c|}
\hline & 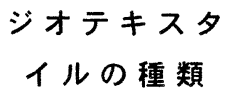 & $\begin{array}{c}\text { 試験前の質量 } \\
(\mathrm{g})\end{array}$ & $\begin{array}{c}\text { 試験 後の質量 } \\
(\mathrm{g})\end{array}$ & $\begin{array}{c}\text { 目詰まり量 } \\
\text { (g) }\end{array}$ & $\begin{array}{c}\text { 単位体積目詰まり量 } \\
\left(\mathrm{g} / \mathrm{cm}^{3}\right)\end{array}$ \\
\hline \multirow{3}{*}{$\begin{array}{c}\text { 六戸細粒分 } \\
\text { 質砂 }\end{array}$} & GTX-SI4 & 4.01 & 4.74 & 0.73 & 0.0202 \\
\hline & $G T X-S 40$ & 10.78 & 12.36 & 1.58 & 0.0164 \\
\hline & GTX-D 80 & 20.62 & 21.06 & 0.44 & 0.0028 \\
\hline \multirow{3}{*}{ 関東ローム } & GTX-S 14 & 3.84 & 4.66 & 0.82 & 0.0227 \\
\hline & GTX - S 40 & 10.3 & 11.06 & 0.76 & 0.0079 \\
\hline & GTX-D 80 & 20.92 & 21.29 & 0.37 & 0.0024 \\
\hline \multirow{3}{*}{ 愛鷹ローム } & GTX - S 14 & 3.49 & 4.18 & 0.69 & 0.0191 \\
\hline & GTX - S 40 & 11.14 & 12.23 & 1.09 & 0.0113 \\
\hline & $G T X-D 80$ & 17.2 & 17.42 & 0.22 & 0.0014 \\
\hline
\end{tabular}


表-4 開孔径以下の粒径に対する試料土層の質量と粒子の通過質量百分率（割合）

\begin{tabular}{c|c|c|c|c|c|c}
\multirow{2}{*}{} & \multicolumn{2}{|c|}{ 六戸細粒分質砂 } & \multicolumn{2}{c|}{ 関東ローム } & \multicolumn{2}{c}{ 愛鷹ローム } \\
\cline { 2 - 7 } & 質量 $(\mathrm{g})$ & 割合 $(\%)$ & 質量 $(\mathrm{g})$ & 割合 $(\%)$ & 質量 $(\mathrm{g})$ & 割合 (\%) \\
\hline GTX-S14 & 2650.62 & 86 & 1473.69 & 51 & 1580.62 & 57 \\
\hline GTX-S40 & 1695.16 & 55 & 1184.73 & 41 & 1247.86 & 45 \\
\hline GTX-D80 & 801.35 & 26 & 953.56 & 33 & 1026.05 & 37 \\
\hline
\end{tabular}

図-7に示す関東ロームの場合には、透水開始から 40 時間までは、各々の $\mathrm{k}$ の值は異なるが、すべての $\mathrm{k}$ が上昇傾向を示している。これは、関東ロームに含ま れる結合水の排出によるものと思われる.すなわち、 本研究ではモールド内の試料を締固めて供試体を作製 したので、関東ロームは乱されていることになり、関 東ロームの物理的性質から考えると、もともと土粒子 構造内に保持されている水が、自由に排出される状態 になり、結果として、透水試験開始による脱気水の浸 入により自由水が排出されたと考えられる。したがっ て、40 時間以降について着目すると、透水係数は、す ベてのジオテキスタイルで減少傾向にあることから、 時間とともに目詰まりが生じていると考えられる.

図-8での愛鷹ロームについては、GTX-S40 の k が最 も小さい. また、いずれのジオテキスタイルも $\mathrm{k} に わ$ ずかな減少傾向が見られ、各々に目詰まりが生じたと 推測される.

図-9での六戸細粒分質砂ついては、GTX-S40 の k が GTX-S14 とGTX-D80 の kより小さい值を示しているが、 各々減少傾向を示していることから目詰まりが生じて いると考えられる. しかし、これらの結果からは種々 の土質に適するジオテキスタイルの評価は判断出来な い. そこで、定水位透水試験後のジオテキスタイルの 単位体積目詰まり量を表- 3 に、試料土層に含まれるジ オテキスタイルの開孔径以下の粒径に対する試料土層 の質量と通過質量百分率を表- 4 に示す. 単位体積目詰 まり量とは、ジオテキスタイルの圧縮量がわずかであ ると仮定して無視することにより、各々のジオテキス タイルの製品仕様に示される厚さを用いて、目詰まり 量をジオテキスタイルの体積で割って求めたものであ る. 表-3より、単位体積目詰まり量は、いずれの試料 においてもGTX-S14>GTX-S40>GTX-D80 である. 一般 に、不織布は厚くなるほど開孔径は小さくなることが 知られている ${ }^{8)}$. 開孔径が小さくなると土粒子の浸入 量が減り、目詰まり量も小さくなると考えられる. 本 研究で得られた単位体積目詰まり量の大小関係は、上 記の不織布の厚さと開孔径の関係に矛盾していないこ とから、単位体積目詰まり量を用いて、目詰まり評価 を行うことは妥当な方法であると考えられる.

\section{2 開孔径に基づいた目詰まり評価の検討}

本研究では目詰まり評価を行うために、ジオテキス

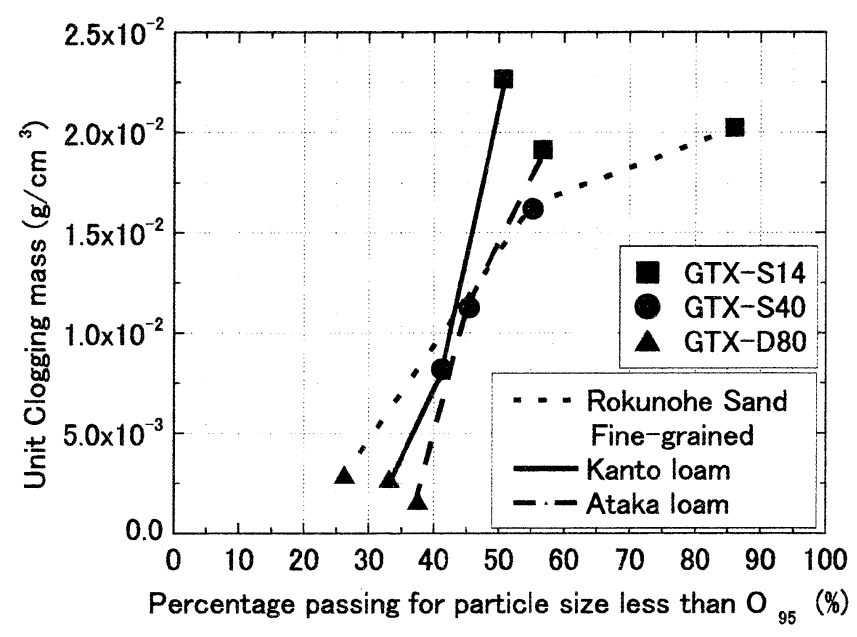

図-10 単位体積目詰まり量一開孔径以下 の粒径の通過質量百分率の関係

タイルの繊維構造内に土粒子が浸入することで目詰ま りが発生すると仮定して、試料土層に含まれる開孔径 以下の粒径の通過質量百分率と目詰まり量の関係に着 目して検討する。

表-3 と表- 4 に基づいて、図- 10 に各ジオテキスタ イルにおける単位体積目詰まり量と開孔径以下の粒径 の通過質量百分率の関係を示す．ジオテキスタイルに 対する単位体積目詰まり量と開孔径以下の粒径の通過 質量百分率は、関東ローム、愛鷹ローム、六戸細粒分 質砂いずれも、GTX-S14>GTX-S40> GTX-D80 となつ ている. また、GTX-D80 について開孔径以下の粒径の 通過質量百分率に着目すると、六戸細粒分質砂が $26 \%$ 、 関東ロームが $33 \%$ 、愛鷹ロームが $37 \%$ の值となり、六 戸細粒分質砂＼cjkstart関東ローム＜愛鷹ロームの関係となる. 次に、図-7〜9での GTX-S14 の試験終了時の透水係数 $\mathrm{k}$ に着目すると、愛鷹ロームは $9.43 \times 10^{-6} \mathrm{~cm} / \mathrm{sec}$ 、関 東ロームは $1.03 \times 10^{-4} \mathrm{~cm} / \mathrm{sec}$ 、六戸細粒分質砂は 6.44 $\times 10^{-4} \mathrm{~cm} / \mathrm{sec}$ の值となり、愛鷹ローム<関東ローム $<$ 六戸細粒分質砂の関係となることがわかる．この結果 から，開孔径以下の粒径の通過質量百分率が小さけれ ば目詰まりが生じにくくなり、透水係数が大きくなる ことが考えられる.

図- 10 において、六戸細粒分質砂における GTX-S14 の開孔径以下の粒径の通過質量百分率の值は、他のデ ータより大きい值となっている.これは、図一３の粒径 加積曲線に示されているように、六戸細粒分質砂の粒 径が $0.1 \sim 0.4 \mathrm{~mm}$ の範囲に多く分布しているためであ 
る. 一方、関東ロームと愛鷹ロームが同様の傾向である のは、図-3からわかるように関東ロームと愛鷹ロームの 粒径加積曲線がほぼ一致しているからであると考えられ る. すなわち、図一 10 に示す六戸細粒分質砂の傾向が 関東ローム、愛鷹ロームと異なるのは、図-3に示す六戸 細粒分質砂の粒径加積曲線が他の試料の粒径加積曲線と 異なっていることが大きく影響していると言える.

本研究に用いた 2 層構造のジオテキスタイル （GTX-D80）は、フィルター層とプロテクション層から成 っている. フィルター層は細径フィラメントで構成され ていて、開孔径が小さいために細粒分の浸入を防ぎ、目 詰まりを抑える機能があるとされている，一方、プロテ クション層は太径フィラメントで構成されていて開孔径 が大きいので目詰まりが生じず、さらに、敷設による損 傷を防ぐ機能があるとされている．図-10の GTX-D80 を見ると、単位体積目詰まり量及び開孔径以下の粒径の 通過質量百分率の值が、他のジオテキスタイルのデータ に比べて、すべての試料土層でほぼ同程度の值を示して いることから、GTX-D80 は本研究で用いたすべての土質 に対して目詰まりが生じにくく、それぞれの土質に適し たジオテキスタイルであると考えられる.これは上述し た 2 層構造特有の繊維構造に起因するものであると思わ れる.

\section{6. まとめ}

種々の地盤材料に対する垂直方向通水性能を検討する ために一連の定水位透水試験を実施した結果、以下の知 見が得られた。

1）本研究で対象とした土質については、土質種類に関 わらず、単位体積目詰まり量は、GTX-S14>GTX-S40 $>$ GTX-D80 となった. この傾向は不織布の厚さが厚 くなればなるほど開孔径が小さくなるという不織布 の厚さと開孔径の一般的な関係に矛盾していないこ とから、本研究で示した単位体積目詰まり量による 目詰まり量の評価は妥当な方法であると考えられる

2）開孔径以下の粒径の通過質量百分率が小さければ、 目詰まりが生じにくくなり、透水係数が大きくなる と考えられる.
3）関東ロームと愛鷹ロームは粒度、単位体積目詰まり 量、開孔径以下の粒径の通過質量百分率がそれぞれ 類似していることから、ジオテキスタイルに対する 適性も類似すると考えられる。

4）本研究の範囲内では、2 層構造の GTX-D80 が試験に 用いたすべての土質で、他のジオテキスタイルに比 べて目詰まりが生じにくいことから、それぞれの土 質に適したジオテキスタイルであると考えられる.

本研究では、短期的な定水位透水試験を行い、垂直方 向通水性能を検討したが、現場での使用条件等の問題か ら、今後、長期的かつ継続的な垂直方向通水性能等を検 討する必要があると考えられる.

\section{参考文献}

1）宮田喜壽，木暮敬二，谷澤芳郎，落合英俊 : 目詰まり不織 布の通水性能に関する実験的考察, 土木学会論文集, No, 596/III-43, 123-130, 1988.6

2）林英雄，森橉：盛土中に敷設するジオテキスタイル排水材 の目詰まりによる透水性低下の予測に関する研究, 土木学 会論文集，No, 510/IV-26, 57-67,1995.3

3）林英雄、森麟: 地山から流出する土粒子による不織布排水 材の目詰まり量と排水性に関する実験的研究、第 28 回土 質工学研究発表会、pp. 2437-2440、1993.6

4）山田貴史, 伊藤秀行, 片岡昌裕, 浅田貢 : 不織布の面内方 向透水性能の低減に関する実験, 第 32 回地盤工学研究発 表会, pp. 2027-2028，1997.7

5）巻内勝彦、峯岸邦夫、塩野真康、増田貴之 : ジオドレーン シート・盛十複合体における水理特性、ジオシンセティッ クス論文集 第 17 巻、pp.173-176、国際ジオシンセティッ クス学会日本支部、2002.12

6）西形達郎, 岩崎高明, 須永誠, 新井克彦:「ジオテキスタ イルの水理特性試験方法」について, ジオテキスタイル試 験方法に関するシンポジウム発表論文集, pp. 9-16, 1994.6

7）木幡行宏, 田中雅史, 佐藤織絵 : ジオテキスタイルフィル タ一の目詰まりによる透水性低下に関する実験的研究, 第 40 回地盤工学研究発表会, pp. 1949-1950, 2005.

8) J.P.Giroud: Granular Filters and Geotextile Filter, Proc. of Geofilters' 96, pp. 565-680, 1996.

Clogging properties of Geotextile filter on permeability test for various geomaterials

$$
\text { Yukihiro KOHATA, Orie SATO, Fumitaka SHIMAYA, }
$$

\title{
Junichi HIRONAKA and Takao HIRAI
}

\begin{abstract}
A series of constant head permeability test was performed by putting in a geotextile between a geomaterial layer and a gravel layer in order to evaluate an effect of geomaterial on the cross-plane flow performance of geotextile filter. As the geomaterials for this study, Ataka loam, Kanto loam, Rokunohe sand with fine-grained and Muroran sand with fine-grained were prepared. Based on test results, it was found that the cross-plane flow performance of geotextile depended on the relationship between an amount of clogging per unit volume on each geotextile and a percentage passing by mass of soil particle size less than an opening size of geotextile. It is expected that a clogging mass and an amount of clogging per unit volume are affected by a fiber structure of geotextile.
\end{abstract}

